OPEN ACCESS

Edited by:

Filippo Maggi,

University of Camerino, Italy

Reviewed by:

Javad Sharifi-Rad,

Shahid Beheshti University of Medical

Sciences, Iran

Angelo Canale,

Università degli Studi di Pisa, Italy

*Correspondence:

Pooja Singh

pooja.ddu@gmail.com

Abhay K. Pandey

abhaykumarpandey.ku@gmail.com

${ }^{\dagger}$ Present address:

Abhay K. Pandey,

World Vegetable Center, South Asia,

Patancheru, Hyderabad, India

Specialty section:

This article was submitted to

Plant Metabolism

and Chemodiversity,

a section of the journal

Frontiers in Plant Science

Received: 23 June 2018

Accepted: 17 August 2018

Published: 10 September 2018

Citation:

Singh P and Pandey AK (2018)

Prospective of Essential Oils of the

Genus Mentha as Biopesticides:

A Review. Front. Plant Sci. 9:1295.

doi: 10.3389/fpls.2018.01295

\section{Prospective of Essential Oils of the Genus Mentha as Biopesticides: A Review}

\author{
Pooja Singh* and Abhay K. Pandey*t \\ Bacteriology and Natural Pesticide Laboratory, Department of Botany, DDU Gorakhpur University, Gorakhpur, India
}

Mentha is a genus from the family Lamiaceae, whose essential oils has long been used in various forms such as in management of plant pathogens and insect pests, in traditional medicine as well as in culinary and cosmetics. Its major chemical components such as menthol, carvone have now been successfully commercialized in the industry as antimicrobials/insecticidal agents. Current review focuses on chemical composition of essential oils of some Mentha species from different geographical regions with their insecticidal (repellent, antifeedant, and ovicidal) and antimicrobial efficacies against bacterial, fungal plant pathogens and insects of stored products. Reports of the researchers on chemical analysis of essential oils of Mentha species revealed that most of the oils being rich in pulegone, menthon, menthol, carvone, 1, 8-cineole, limonene and $\beta$-caryophyllene. Reviewed literature revealed that, essential oils from different Mentha species possess potential antimicrobial activity against plant pathogens and have insecticidal activity against stored product insects. Thus, antimicrobial and insecticidal properties of essential oils of Mentha species offer the prospect of using them as natural pesticides with a commercial value, having social acceptance due to its sustainability and being environment friendly.

Keywords: Mentha, essential oil, antimicrobial, chemical composition, insecticidal

\section{INTRODUCTION}

In the plant kingdom, family Lamiaceae (syn. Labiatae) is endowed with several medicinal and aromatic plants. The family comprises of more than 232 genera and approximately 7200 species (Harley et al., 2004). Most of the Lamiaceae plants are found to accumulate secondary metabolites such as terpenes/essential oils and other components, mainly in the epidermal glands of leaves, stems and reproductive structures. These terpenes/essential oils have several applications in cosmetics, food industry, medication and perfumery. The genus Mentha is a very important taxon in the family Lamiaceae and includes $25-30$ species that grow worldwide especially in the South Africa, Australia and temperate regions of Eurasia (Dorman et al., 2003). The taxon has a significant importance both commercial as well as medicinal. Indeed, different plant parts such as leaves, flowers and stems of this genus are frequently used in herbal medicine, teas or as additives in spice mixtures for various foods to offer aroma and flavor (McKay and Blumberg, 2006). Additionally, Mentha spp. has been used as a folk remedy for aliment ulcerative, anorexia, nausea, flatulence, bronchitis, liver complaints, and colitis due to its stimulant, antiemetic, diaphoretic, carminative, antiinflammatory, analgesic, emmenagogue, antispasmodic, and anticatarrhal activities (Iscan et al., 2002; Moreno et al., 2002). Commercially, the most 
important mint species are spearmint (Mentha spicata), peppermint (M. x piperita), and corn mint (M. canadensis). Among these species, corn mint is only cultivated for oil production (Oudhia, 2003). Peppermint oil is also used for its essential oils and mostly because of its major components menthol and menthone (Mimica-Dukic et al., 2003). On the other hand spearmint is rich in carvone and is widely used as spices and cultivated in several countries (Kokkini et al., 1995). Peppermint oil is applied to flavor the pharmaceuticals and most of the oral preparations (toothpastes, dental creams, and mouth washes). The plant is also used as flavoring agent in confectionery, cough drops, chewing gums, and some of the alcoholic liqueurs. For internal uses it is used in medicines and its pleasant taste makes it an excellent gastric stimulant (Dorman et al., 2003). Due to increasing interest in tribal and traditional phyto-therapeutics methods, many recent investigations have been carried out to examine the medicinal properties of these herbs for human welfare. McKay and Blumberg (2006) published review on the bioactivity and potential health activity of $M$. piperita. Their studies were only focused on medicinal properties and they took only one plant species during the compilation. Kumar et al. (2010) reviewed insecticidal properties of Mentha oil and extract, but they only covered the insecticidal properties against storage insects. Still, nobody has compiled a review on antibacterial, antifungal activities and insecticidal activities of Mentha oil against plant pathogens/storage insect pests. Henceforth, in this review, we discuss latest advances in the chemistry, antimicrobial and insecticidal activities of essential oils from different Mentha species of different regions. The keywords used to survey the literature are Mentha essential oil, chemical composition, antifungal, antibacterial and insecticidal. For a comprehensive literature overview, we analyzed the published phytochemical and biological data available through several search engines, such as ${ }^{\circledR}$ SciFinder, ISI ${ }^{\circledR}$ Web of Science, ${ }^{\circledR}$ Scopus, and ${ }^{\circledR}$ Google Scholar, as well as several libraries viz., National Science Library, New Delhi; National Medical Library, New Delhi; IARI Library, New Delhi; CIMAP, Lucknow, and FRI Library, Dehradun of India.

\section{ESSENTIAL OIL COMPOSITION OF Mentha SPECIES}

Essential oils of higher plants are volatile in nature and a complex mixture of monoterpenes $\left(\mathrm{C}_{10}\right)$ and sesquiterpenes $\left(\mathrm{C}_{15}\right)$; although diterpenes $\left(\mathrm{C}_{20}\right)$ may also be present, and a variety of low molecular weight aliphatic hydrocarbons, alcohols, acids, aldehydes, acyclic esters or lactones and exceptionally $\mathrm{N}$ - and S-containing compounds, coumarins and homologs of phenyl-propanoids (Dorman and Deans, 2000; Sharifi-Rad M. et al., 2017; Sharifi-Rad J. et al., 2017). The whole Mentha plant possesses essential oils; however, the amount of oil varied depending upon the species and method of isolation. Essential oils from different Mentha species have been isolated by different methods such as hydrodistillation using Clevenger apparatus or pharmacopeia distillation apparatus ( $\mathrm{Li}$ et al., 2013). Menthol and pulegone present in the essential oil of
Mentha species are the substances that give the mints their characteristic aromas and flavors (Lubbe and Verpoorte, 2011). Some investigators reported that aroma and flavor of spearmint is due to presence of carvone (Hussain et al., 2010a). Instead of menthol, pulegone and carvone, chemically essential oil of Mentha species is composed of other different major and minor components. Several investigations have been carried out on the chemical composition of different samples of Mentha species from different geographical regions. The Mentha species which are described here in Table $\mathbf{1}$ for their essential oil chemistry have been collected from the different geographical regions. Most of the species were collected from Bangladesh, Brazil, Cameroon, Egypt, Europe, Guinea, India, Iran, Italy, Tunisia, Mali, Nigeria, Pakistan, Rwanda, Thailand, Togo, Turkey, Um Ruaba, and Yaounde. The studies revealed that chemical composition and their respective percentage of different Mentha species varied depending upon the origins of the plant and species (Table 1). Table shows that the species investigated for the chemical composition of the oil from different countries were $M$. piperita, M. pulegium, M. longifolia, $M$. arvensis, $M$. suaveolens, $M$. rotundifolia, $M$. officinalis, $M$. spicata, M. mozaffarianii, $M . x$ villoso-nervata, $M$. viridis, and M. rotundifolia. Table $\mathbf{1}$ also shows that there is a significant variation in chemical composition of the same species. This may be due to the time of oil extraction or their occurrence in different geographical location. The compositional variation in the essential oil is also may be due to harvesting time at different stage, drying as well as extraction methods (Rohloff et al., 2005). Some factor like physiological and environmental conditions, genetic and evolution also determine the chemical variability of Mentha essential oils (Figueiredo et al., 2008). Additionally, most of the species chemically characterized were rich in pulegone, menthon, menthol, carvone, 1, 8-cineole, limonene, and $\beta$-caryophyllene. The chemical structures of major compounds are depicted in Figure 1.

\section{BIOLOGICAL ACTIVITY OF ESSENTIAL OILS OF Mentha SPECIES}

In recent years researchers have focused their attention on the biological activities of essential oils (EOs) and their constituents of different Mentha species from several research organizations of the world. Bacteria and fungi are important pathogens of the crops as well as stored food commodities; reported to cause 4050\% losses (Pandey et al., 2017). Here we have reviewed the activity of essential oils of different Mentha species against plant fungal pathogens and stored product insects, their mechanism as well as their applications in the postharvest.

\section{Mentha Essential Oil as an Antibacterial Agent}

Bacteria associated with plants causes serious diseases in agricultural crops as well as in postharvest commodities throughout the world (Vidhyasekaran, 2002). The yield loss reported due to bacterial diseases in pre and postharvest is about $30-40 \%$ of crop produce per year. Basically, Xanthomonas, Pseudomonas, and Erwinia are the main genera of bacteria, 
TABLE 1 | Chemical composition of different species of the Mentha oil.

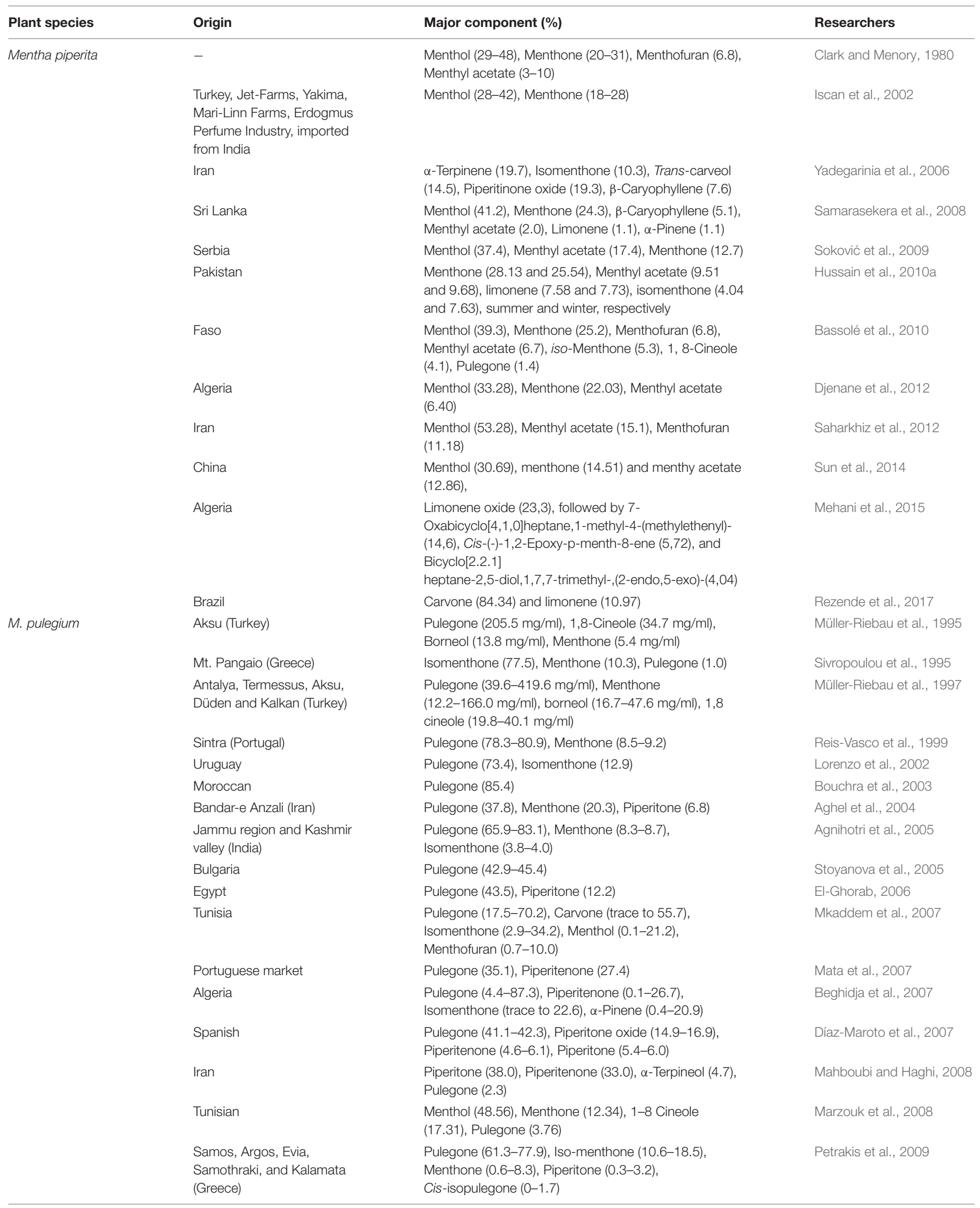


TABLE 1 | Continued

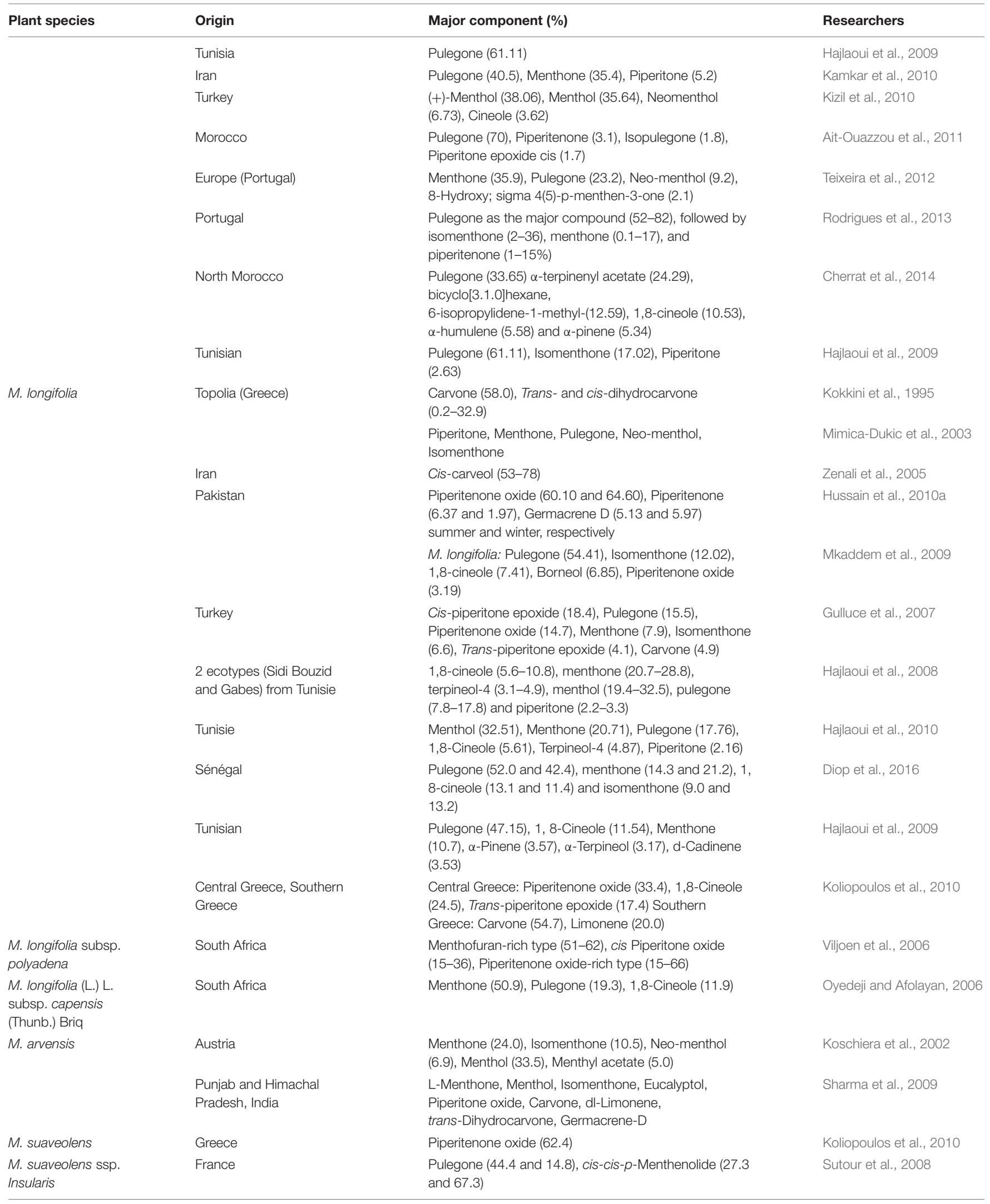


TABLE 1 | Continued

\begin{tabular}{|c|c|c|c|}
\hline Plant species & Origin & Major component (\%) & Researchers \\
\hline \multirow[t]{2}{*}{ M. rotundifolia } & Morocco & $\begin{array}{l}\text { Menthol (40.50), Menthone (5.0), Menthyl acetate } \\
\text { (4.50), Menthofuran (4.20), Oxyde de piperitone (3.80), } \\
\text { Linalyl acetate (3.50), Neomenthol (3.20), Piperitone } \\
\text { (3.10), Isomenthone (2.50), 1,8-Cineole (2.40), Linalool } \\
\text { (2.0), Limonene (1.80), Geraniol (1.70), Myrcene (1.60), } \\
\text { Geranyl acetate (1.50), Trans-Sabinene hydrate (1.40) }\end{array}$ & Derwich et al., 2010 \\
\hline & Tunisia & $\begin{array}{l}\beta \text {-Caryophyllene (26.67), Germacrene D (12.31) and } \\
\text { Carveol (7.38) }\end{array}$ & Riahi et al., 2013 \\
\hline M. officinalis & Greece & $\begin{array}{l}\text { Terpin-4-ol (15.8), Caryophyllene oxide (13.2), Sabinene } \\
\text { (12.9), } \beta \text {-Pinene (12.1), Trans-caryophyllene (10.2) }\end{array}$ & Koliopoulos et al., 2010 \\
\hline \multirow[t]{4}{*}{ M. spicata } & Soliman Tunisian & Carvone (40.8) and limonene (20.8) & Snoussi et al., 2015 \\
\hline & Greece & Piperitenone oxide (35.7), 1,8-Cineole (14.5) & Koliopoulos et al., 2010 \\
\hline & Pakistan & $\begin{array}{l}\text { Carvone ( } 59.50 \text { and } 63.24) \text {, Limonene ( } 10.44 \text { and } \\
\text { 9.09), 1,8-cineol ( } 6.36 \text { and } 4.51) \text { summer and winter, } \\
\text { respectively }\end{array}$ & Hussain et al., 2010b \\
\hline & Serbia & Carvone (69.5) and Menthone (21.9) & Soković et al., 2009 \\
\hline M. mozaffarian & Iran & Piperitone (51.0) & Sam-Daliri et al., 2016 \\
\hline M. $x$ villoso-nervata & Topolia & $\begin{array}{l}\text { M. } x \text { villoso-nervata: Carvone (80.1), Trans- and } \\
\text { cis-dihydrocarvone }(0.1-5.4)\end{array}$ & Kokkini et al., 1995 \\
\hline M. viridis & & Carvone (50.47), 1,8-Cineole (9.14), Limonene (4.87) & Mkaddem et al., 2009 \\
\hline M. rotundifolia & Spain & $\begin{array}{l}\text { Rotundifolone (10.4), Piperitol (57.6), Rotundifolone } \\
\text { (33.2), Diosphenol (47.7) }\end{array}$ & Perez Raya et al., 1990 \\
\hline
\end{tabular}

play major role in causing plant diseases (Agrios, 2005). There are several commercial bactericides available in the markets against these bacterial pathogens, however, their indiscriminate use caused several health hazards to human beings as well side effect to the host plants (Louws et al., 2001). Additionally, there are several strains of bacterial pathogens which have developed resistance against commercial bactericides due to the change in climate. Plant bacteriologists reported that plant pathogenic bacteria readily acquire resistance to copper bactericides and streptomycin (Stall and Thayer, 1962; Marco and Stall, 1983; Cuppels and Elmhirst, 1999). Therefore, researchers looked for the alternatives that would resolve the resistance problems, be less harmful and would be effective to control the bacterial pathogens. Potentiality of many essential oils and their constituents have been tested against several plant pathogenic bacteria using different methods like agar dilution, disk diffusion, agar well and broth dilution assays (Perricone et al., 2015), however, regarding the Mentha essential oils there are few literature available from past to recent. Essential oils from Mentha piperita collected from different provinces like Turkey, Yakima, MariLinn Farms, and A Erdogmus Perfume Industry imported from India exhibited stronger antibacterial activity against $P$. syringae pv. syringae, Pseudomonas syringae pv. tomato, $P$. syringae pv. phaseolicola, Xanthomonas campestris pv. campestris, and $X$. campestris pv. phaseoli at $0.07-1.25 \mathrm{mg} / \mathrm{ml}$ range of MIC values (Iscan et al., 2002) by broth dilution bioassay. They also reported that some chemical constituents such as menthol and menthone derived from $M$. piperita essential oil showed potent MIC value against the plant pathogenic bacteria. Menthol (Polarome, Jersey City, NJ, United States) showed $0.625 \mathrm{mg} / \mathrm{ml}$ MIC value against $X$. campestris pv. phaseoli, 1.25 against Ps. syringae pv. phaseolicola, 0.07 against Ps. syringae pv. tomato and 0.156 against $P$ s. syringae pv. syringae and $X$. campestris pv. campestris. Similarly, (-)-menthone (Fluka, Germany) inhibited the growth of $X$. campestris pv. phaseoli, $P$. syringae pv. phaseolicola, $P$. syringae pv. syringae at $2.5 \mathrm{mg} / \mathrm{ml}$ MIC value, while of $X$. campestris pv. campestris and $P$. syringae pv. tomato at $1.25 \mathrm{mg} / \mathrm{ml}$. Similar investigation was carried out by Soltani and Aliabadi (2012), they reported that essential oil from $M$. piperita and M. spicata showed same level of toxicity against $X$. campestris pv. juglandis. Vasinauskienë et al. (2006) evaluated seven essential oils including $M$. piperita and found that this oil is effective against phytopathogenic bacteria with zone of inhibition (ZOI) $2-6 \mathrm{~cm}$ against $P$. syringae pv. syringae, $P$. syringae pv. tomato, Erwinia carotovora subsp. carotovora and 6-12 cm against $X$. vesicatoria in disk diffusion bioassay. Minimum bactericidal concentration of $M$. spicata essential oils varied from 6 to $40 \mathrm{mg} / \mathrm{ml}$ in micro agar broth dilution method against Acidovorax avenae subsp. citrulli (Aac) causing seed borne bacterial disease in different commercially important crops. In another investigation, $1 \mu \mathrm{l}$ dose of $M$. arvensis essential oil was more effective than streptomycin and showed a variable range of ZOI against Pantoea agglomerans $(11.10 \mathrm{~cm})$, Erwinia amylovora $(10.9 \mathrm{~cm})$, Pantoea dispersa $(8.8 \mathrm{~cm})$, P. fluorescens $(5.2 \mathrm{~cm})$, and Ps. syringae pv. syringae $(5.0 \mathrm{~cm}$ ) (Kokoskova et al., 2011). From the above investigations we can speculate that a variable range of efficacy was reported for different species of Mentha oil against the same bacterial species. This may be due to the use of different methodology during the screening, variability in bacterial strains and also variation in the chemical constituents of the essential oils of different Mentha species. The significant antibacterial activity observed for the different species 
of Mentha oil is due to the presence of phenolic compounds like menthol and carvacrol (Sivropoulou et al., 1995; Dorman and Deans, 2000). These phenolic compounds form complexes with bacterial enzymes and protein and inhibited the growth of bacterial pathogens (Rhouma et al., 2009). In the bacterial membrane phenolic compounds dissolved through penetration and where they interact with the cell metabolism cause the disruption of plasma membrane which increase the permeability and depolarize its potential finally led to death of bacteria (Oussalah et al., 2006; Xu et al., 2008).

\section{Mentha Essential Oil as Antifungal Agent}

In the agriculture, fungi are the major plant pathogen in the field crops and storage food commodities (Sharifi-Rad et al., 2018), where by producing mycotoxins and several toxic metabolites they affect the nutritional value of food and make them unhealthy for human consumption (Paranagama et al., 2003; Sonker et al., 2015). Fungi reported to infect the plants in the field and storage include the genera of Aspergillus, Cladosporium, Fusarium, Penicillium, Alternaria, Macrophomina, Rhizoctonia, Colletotrichum, and Botrytis (Pandey et al., 2017), they are responsible for the $40-50 \%$ loss of the crop produce. For the management of these pathogens several synthetic fungicides like carbendazim, capton, and mancozeb are available in the market, however, these fungicides have their own limitations, use of such fungicides cause several side effect to the host as well as beneficial microorganisms. Also due to climate change some fungal pathogens has started to develop the resistance against the commercial fungicides (Chang et al., 2007; Price et al., 2015). Therefore, researchers were use the botanical fungicides for the management of these fungal pathogens which have broad range of toxicity, eco-friendly and renewable in nature. During recent years several essential oils have been proved as effective fungitoxicant against these pathogens including Mentha essential oils (Iacobellis et al., 2005; Teixeira et al., 2012; Goudjil et al., 2016). For the screening of essential oils against fungal pathogens basically few methods such as poison food method (Mishra et al., 2013), inverted Petri plate method (Pandey et al., 2013) and agar dilution methods (Vishvakarma et al., 2015) have been used. Poison food method was used to develop contact fungicides, while inverted Petri plate method was used to develop fumigant fungicides against the fungal pathogens. Mentha longifolia oil was fungistatic against Aspergillus niger, A. versicolor, Cladosporium fulvum, Fusarium tricinctum, F. sporotrichioides, Penicillium funiculosum, $P$. ochrochloron at $2.5 \mu \mathrm{l} / \mathrm{ml}$ and against C. cladosporioides at $12.5 \mu \mathrm{l} / \mathrm{ml}$ (MimicaDukic et al., 2003). The MIC of M. piperita varied from 1.13 to $2.25 \mathrm{mg} / \mathrm{ml}$ and 2.25 to $4.5 \mathrm{mg} / \mathrm{ml}$ for P. digitatum, A. flavus, A. niger, Mucor spp, and F. oxysporum (Tyagi and Malik, 2011). The essential oil and their chemical constituent's like menthone and $\beta$-caryophyllene showed a different degree of inhibition against twenty-five microorganisms with more efficacy against A. niger (Marotti et al., 1994). Džamić et al. (2010) reported that $10 \mu \mathrm{l} / \mathrm{ml}$ of $M$. longifolia essential oil showed fungicidal activity against Aspergillus and Fusarium species, P. funiculosum, Trichoderma viride and $2.5 \mu \mathrm{l} / \mathrm{ml}$ to C. fulvum, C. cladosporioides, and $P$. ochrochloron. A variable range of inhibition zones (1132, 19-30, and 16-29 $\mathrm{mm}$ ) were reported for M. longifolia, M. piperita, and M. spicata essential oils, respectively, against Rhizopus solani, A. niger, and Alternaria alternata infecting stored food commodities. Correspondingly, these oils showed $44.1-157.8,52.9-130.1$, and $53.2-133.1 \mu \mathrm{g} / \mathrm{mL}$ respective range of MICs values against these fungal strains (Hussain et al., 2010a). Our laboratory bioassay revealed that essential oil of $M$. arvensis was found to be inhibited the growth of postharvest fungi of pigeon pea seeds and papaya fruits especially Aspergillus and Fusarium species (Singh, 2010; Pandey and Tripathi, 2011). However, on the contrary, results of Bouchra et al. (2003) showed that $M$. pulegium oil had moderate activity against Botrytis cinerea at $250 \mathrm{ppm}$ where only $58.5 \%$ growth inhibition was reported. This differentiation in the toxicity may be due to the oils used from different plants and also it depends on the fungal strains of different hosts. M. piperita exhibited fungicidal nature against Aspergillus strains at $0.5-4 \mu \mathrm{l} / \mathrm{ml}$ (Saharkhiz et al., 2012). Fungal pathogens such as Geotrichum citri-aurantii, $P$. digitatum, and $P$. italicum causing fruit decay in citrus were controlled when treated with $750 \mu \mathrm{l} / \mathrm{l}$ dose of $M$. spicata oil (Regnier et al., 2014). Also formulation of essential oils has been tested for the control of fungal pathogens and they proved more effective than that of pure oil due to their formulation in adjuvant. The encapsulated oil of M. piperita was very effective at $800 \mathrm{ppm}$ in controlling A. flavus causing postharvest rot in food commodities than that of pure oil which failed to caused complete mycelial inhibition at tested concentration range (upto $3000 \mathrm{ppm}$ ) (Beyki et al., 2014). M. piperita oil is also found to be effective against tomato pathogen F. oxysporum f.sp. lycopersici causing wilting with MIC of $0.3 \mu \mathrm{l} / \mathrm{ml}$ of air and at increased MFC, i.e., $>0.6 \mu \mathrm{l} / \mathrm{ml}$ of air (Djordjevic et al., 2013). This oil has also been reported as effective antifungal agent against few soil borne pathogens Drechslera spicifera, F. oxysporum f.sp. ciceris, and Macrophomina phaseolina at effective concentration $1600 \mathrm{ppm}$ by agar dilution method (Moghaddam et al., 2013). Some Mentha oils showed poor efficacy and were reported as phytotoxic in nature. In this regard, Lopez-Reyes et al. (2013) reported that M. arvensis oil (10\% concentration) was poor antifungal agent in controlling $B$. cinerea and $M$. laxa growing on apricots and oil was also phytotoxic. Also, in their earlier research (Lopez-Reyes et al., 2010), 1 and 10\% essential oil emulsion of M. arvensis was poor effective than that of others oils and fungicide tebuconazole in controlling fruit rot in apple due to B. cinerea and P. expansum. Similar results were reported for the fungitoxicity of $M$. arvensis oil against F. oxysporum causing wilt in crops (Gupta et al., 2011) at 10 and $20 \%$ oil concentration. In macro and microdilution methods, $M$. spicata essential oil exhibited $1.0-2.5 \mu \mathrm{l} / \mathrm{ml}$ range of MIC value in ethanol and $0.5-1.5 \mu \mathrm{l} / \mathrm{ml}$ in Tween against plant pathogens namely A. niger, A. ochraceus, A. versicolor, A. flavus, A. terreus, A. alternata, P. ochrochloron, P. funiculosum, C. cladosporioides, T. viride, F. tricinctum, and Phomopsis helianthi. However, MICs of M. piperita essential oil were higher, 1.5$3.0 \mu \mathrm{l} / \mathrm{ml}$ in ethanol and $1.0-2.5 \mu \mathrm{l} / \mathrm{ml}$ in Tween against the same pathogens (Soković et al., 2009). These both oils, i.e., M. spicata and $M$. piperita also performed significant antifungal activity against major pathogens of button mushroom, i.e., Verticillium 
<smiles>CC(C)=C1CC[C@@H](C)CC1=O</smiles>

Pulegone<smiles>CC(C)[C@H]1CC[C@@H](C)CC1=O</smiles>

Menthon<smiles>CC1CCC(C(C)C)C(O)C1</smiles>

Menthol<smiles>C=C(C)[C@H]1CC=C(C)C(=O)C1</smiles>

Carvone

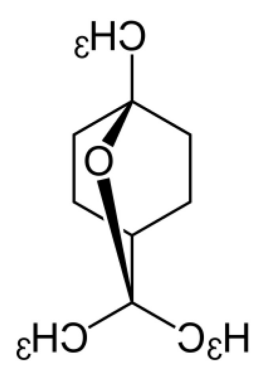

1, 8-cineole

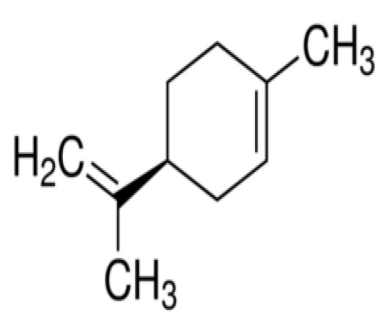

Limonene<smiles>C=C1CC/C=C(/C)CC[C@@H]2[C@@H]1CC2(C)C</smiles>

$\beta$-Caryophyllene

FIGURE 1 | Active compounds of different species of Mentha essential oil.

fungicola and T. harzianum (Sokovic and van Griensven, 2006) by micro and macro-dilution methods. M. spicata oil was fungistatic at $0.5-2.5 \mu \mathrm{l} / \mathrm{ml}$, while fungicidal at $1.5-2.5 \mu \mathrm{l} / \mathrm{ml}$. While MIC $(2.5-3.5 \mu \mathrm{l} / \mathrm{ml})$ and MFC $(3.0-4.0 \mu \mathrm{l} / \mathrm{ml})$ values of M. piperita oil (Sokovic and van Griensven, 2006) increased by micro and macro-dilution methods.

Chemical constituents from essential oils from Mentha species has also been reported as potential antifungal agent against plant pathogenic fungi. Monoterpenoid, i.e., spearmint gave $100 \%$ mycelial inhibition of postharvest fungi $A$. terreus and $F$. oxysporum, and $91 \%$ of $P$. expansum and $V$. dahliae at $1 \mu \mathrm{l} / \mathrm{l}$ dose and also at the same dose this terpenoid inhibited $100 \%$ conidial production of all these tested fungi (Kadoglidou et al., 2011). Menthol extracted from M. spicata showed MICs of $0.25-1.5 \mu \mathrm{l} / \mathrm{ml}$ in ethanol and $0.05-1.0 \mu \mathrm{l} / \mathrm{ml}$ in Tween by microdilution method (Soković et al., 2009), while carvone of M. piperita possessed higher antifungal activity with MICs value $0.25-1.0 \mu \mathrm{l} / \mathrm{ml}$ in ethanol and $0.05-0.5 \mu \mathrm{l} / \mathrm{ml}$ in Tween by the same method. Limonene showed moderate fungistatic activity against aforesaid pathogens with MICs by microdilution method were $6.0-11.0 \mu \mathrm{l} / \mathrm{ml}$ in ethanol and $5.0-9.0 \mu \mathrm{l} / \mathrm{ml}$ in Tween (Soković et al., 2009). This variation in MICs of M. spicata and M. piperita may be due to the variation in chemical ingredients among the plant species, methodology used and also different fungal strains used during the bioassays. The greater efficacy of M. piperita and M. spicata reported were due to the presence of menthol and carvone. This antifungal activity of essential oil may be due to presence of oxygenated terpenes or phenolic structure. This is speculated that the hydroxyl group of phenol and alcohol might be an important factor of their antifungal activity (Griffin et al., 2000).

Researchers reported that several monoterpenes acts on cell membrane by affecting lipid fraction of plasma membrane, causing leakage of intracellular membrane (Trombetta et al., 2005). Monoterpenoids are also found to affect respiratory enzymes of fungi (Cox et al., 2000), inhibited the uptake of microbial oxygen and oxidative phosphorylation. This could be a reason why some essential oils rich in monoterpenic components were found to be effective against the plant pathogenic fungi. These all results on the use of essential oils and their chemical constituents of Mentha species revealed that these oils could find practical application in the prevention and protection of fungal infections of plants in the field as well as in the storage conditions.

\section{Mentha Essential Oils as Repellent, Insecticidal, Antifeedant Agents Against Stored Insect Pests and Its Mechanism of Action}

In the tropical countries insects are the major destroyers of stored food commodities especially of cereals and pulses. The important storage insect pests such as pulse beetles (Callosobruchus species), maize weevil (Sitophilus zeamais), rice weevil (S. oryzae), and red 
flour beetle (Tribolium species) are reported to cause about $60 \%$ loss in cereals and pulses (Singh et al., 2012). These problems arise due to agroclimatic conditions as well as improper storage facilities. In recent years, there are several chemical and nonchemical methods were used for the control of these insect pests. Use of commercial fumigants against these stored insect pests is either effective, but due to climate change insects have started develop resistant against these fumigants (Chaudhry, 1997) or also these insecticides have several side effect on human beings. Use of essential oils is one of the non-chemical options for the management of these insect pests which have been proved as effective method for the management of stored product insects and also have fewer chances of resistance problems against these insect pests. Earlier, Kumar et al. (2010) reviewed the insecticidal properties of extract and essential oils from different Mentha species against storage as well as field insects' pests. In continuation of these reports, here we are updating the report on 2000 onwards, dealing only on the efficacy of essential oils against stored insect pests. Attempts have been made to determine the insecticidal efficacy of essential oils and their constituents from different Mentha species against stored product insects. Mentha haplocalyx $\left(31.5 \mu \mathrm{g} / \mathrm{cm}^{2}\right)$ essential oil at $72 \mathrm{~h}$ of exposure showed $83 \%$ repellent activity against $T$. castaneum when assessed by area preference method (Wagan et al., 2016). M. haplocalyx essential oil and its main constituent's menthol, menthyl acetate, limonene, and menthone had $\mathrm{LD}_{50}$ values of $16.5,7.91,5.96$, and $13.7 \mathrm{~g}$ /adult, respectively, against Lasioderma serricorne adults in contact toxicity bioassay and among all menthol showed higher repellent activity (Zhang et al., 2015). In fumigant toxicity test, $M$. spicata showed $27.52 \mu \mathrm{l} / \mathrm{l}$ of air $\mathrm{LC}_{50}$ values against Rhyzopertha dominica adults affecting stored maize (Nubia et al., 2016). However, in their study this oil was reported as poor fumigant than that of Ocimum basilicum oil. However, M. spicata essential oil exhibited $100 \%$ mortality to $C$. chinensis during a fumigation test with an $\mathrm{LC}_{50}$ value of $0.003 \mu \mathrm{l} / \mathrm{ml}$ air after $24 \mathrm{~h}$ of treatment and $100 \%$ repellency at $0.025 \mu \mathrm{l} / \mathrm{ml}$ air concentration. Oil showed $98.46 \%$ oviposition deterrence, $100 \%$ ovicidal activity, $88.84 \%$ larvicidal activity, $72.91 \%$ pupaecidal activity, and $100 \%$ antifeedant activity against C. chinensis (Kedia et al., 2014). M. spicata oil showed a more than $80 \%$ mortality of Ephestia kuehniella (Zeller) and Plodia interpunctella (Hubner) at $2.5 \mathrm{ml} / \mathrm{l}$ dose and $2 \mathrm{~h}$ of exposure times (Eliopoulos et al., 2015). They found that oil caused 50$60 \%$ of egg mortality, and 18 and $28 \%$ of larval and pupal mortality, respectively, at same dose and $24 \mathrm{~h}$ of exposure. In T. castaneum, $M$. arvensis oil was found to reduce 67.50 and 61.25\% acetylcholinesterase activity over control (Mishra et al., 2014) after $24 \mathrm{~h}$ of fumigation. Saroukolai et al. (2014) reported that M. spicata essential oil showed 259.73 and 75.31 ppm LC $_{50}$ value against fourth star larvae of potato beetle Leptinotarsa decemlineata (Say) by fumigant bioassay and oil also exhibited $39.26 \%$ feeding deterrent index against the adults at $16 \mathrm{ppm}$. M. pulegium essential oil and its major component, pulegone, showed potent insecticidal activity against mushroom scatopsid flies, Scatopse spp. (after $0.5 \mathrm{~h}, \mathrm{LC}_{50}=0.17$ and $0.13 \mu \mathrm{l} / \mathrm{L}$ air, respectively) in fumigant bioassay and $100 \%$ mortality of adults were observed at $4 \mathrm{~h}$ of exposure period (Gurkan and Fedai,
2013). In another study, adults of T. castaneum and C. maculatus were killed by $M$. longifolia essential oils at $13.05 \mu \mathrm{l} / \mathrm{l}$ air $\mathrm{LC}_{50}$ value by fumigant bioassay (Abbas and Javad, 2012). Halit et al. (2012) studied the fumigant effect of three essential oils of the genus Mentha such as M. spicata, M. villoso-nervata, and M. piperita against S. granarius. Among these M. villoso-nervata exhibited $90 \%$ mortality of adults by fumigant bioassay, while its main constituent carvone exhibited $100 \%$ mortality at $24 \mathrm{~h}$ of exposure with $0.024 \mu \mathrm{l} / \mathrm{ml} \mathrm{LC}_{50}$ value. Thus, $M$. villosonervata and carvone can be commercialized as potent insecticidal agent against $S$. granarius. Leaf essential oil of Mentha species possessed $55 \%$ mortality after $48 \mathrm{~h}$ of exposure with $\mathrm{LD}_{50}$ values $0.044 \mu \mathrm{l} / \mathrm{ml}$ by topical application and $3.51 \mu \mathrm{l} / \mathrm{cm}^{2}$ by fumigant application against the T. castaneum adults (Franz et al., 2011). Author reported that this oil is poor insecticidal agent than that of Cymbopogon citratus. It was found that $1.75 \mu$ l of essential oil per $0.5 \mathrm{ml}$ acetone dose of $M$. viridis strongly repelled (63 $81 \%)$ S. granarius adults, thus this oil can be used in organic food production as a repellent and insecticidal agent (Somaye, 2010). Also 100\% mortality of S. granarius was achieved by M. spicata subsp. tomentosa and M. spicata var. formasa essential oils at $1 \mu \mathrm{l} / \mathrm{l}$ air and the exposure periods of 36 and $48 \mathrm{~h}$ and potent mortality of adults at $0.5 \mu \mathrm{l} / \mathrm{l}$ air and an exposure period of $48 \mathrm{~h}$ (Irfan et al., 2009). In the study of Mohamed and Abdelgaleil (2008) M. microphylla exhibited potent fumigant activity against $T$. castaneum $\left(\mathrm{LC}_{50}=4.51 \mu \mathrm{l} / \mathrm{l}\right)$ and $S$. oryzae $\left(\mathrm{LC}_{50}=0.21 \mu \mathrm{l} / \mathrm{l}\right)$. Thus, this oil can be used as protectant against this insect. M. longifolia essential oil exhibited $100 \%$ mortality of $S$. zeamais deteriorating maize at $0.50 \mu \mathrm{l} / \mathrm{g}$ dose in contact toxicity bioassay with $100 \%$ repellency at the same dose (Odeyemi et al., 2008). M. viridis essential oil showed more that $50 \%$ mortality of C. maculatus at $235 \mathrm{ppm}$ dose of essential oil and also reduced $67.4 \%$ egg hatching and $72 \%$ of progeny emergence at $300 \mathrm{ppm}$ dose (Derbalah and Ahmed, 2011). Inhibition of oviposition in insects by essential oils is also an important criterion to manage the stored product insects. There are several essential oil including Mentha are reported as effective ovipositional inhibitor against eggs of stored product insects. Kumar et al. (2009) reported that essential oil from Mentha species is very effective and completely inhibited oviposition of C. chinensis at $200 \mu \mathrm{l} / \mathrm{l}$ and protected seed (94.05\%) from biodeterioration of $C$. chinensis. Against adults of $C$. maculatus, Mentha oil showed $4.43 \mu \mathrm{l} / \mathrm{l}$ air $\mathrm{LC}_{50}$ values and at $1.01 \mu \mathrm{l} / \mathrm{l}$ air dose possessed anti acetylcholinesterase activity (Al-Sarar et al., 2014).

We have described here that insecticides based on essential oil are the good options for the management of insect pests hazardous and resistance problems of the commercial insecticides. To combat with increasing resistance rate in commercial insecticides, identification of novel effective insecticidal compounds is essential. Researchers reported that essential oil based botanical insecticides have wide range of target action on insect pests. When insects are exposed to the essential oils, breakdown of the nervous system of insects occurs (Kostyukovsky et al., 2002). The main target sites of essential is octopaminergic system (Figure 2) which plays a key role as a neurotransmitter, neurohormone, and neuromodulator 


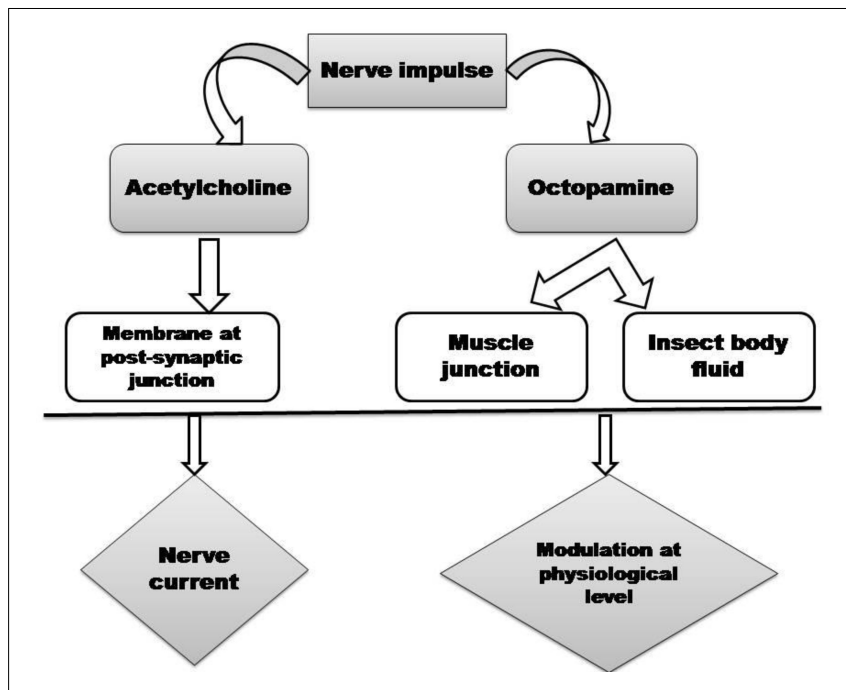

FIGURE 2 | Target sites as promising neurotransmitter mediated toxic action of essential oils in insects. in invertebrate systems, with a physiological role analogous to norepinephrine in vertebrates (Shaaya and Kostyukovsky, 2006). During the insecticidal activity of the essential oils, the mechanism behind the insect mortality is that the volatiles penetrates in the insect body via respiratory system and results in abnormal breathing which leads to asphyxiation and final death of insects (Pare and Tumlinson, 1999). Some investigators also reported that acetylcholinesterase enzyme activity in insect is also inhibited by the essential oil and constituents (Picollo et al., 2008) which lead to the blockage of nerve impulse, later paralysis and then death of the insects occurs. Miyazawa et al. (1998) reported that three Mentha oils viz., M. aquatica, M. gentilis, and $M$. arvensis essential oils significantly inhibited acetylcholinesterase (AChE) activity and their $\mathrm{IC}_{50}$ values were in the range of $28-32 \mu \mathrm{g} / \mathrm{ml}$. Mentha essential oils also showed oviposional activity against the stored insects. This may be due to either death of the insects before their egg laying, failure of live females to lay eggs when they come in contact with essential oils (Pandey et al., 2011). Since Mentha essential oils are made up of terpenic and phenolic chemical constituents, which affect the octopamine receptor and inhibit the acetyl cholinesterase of the larvae and pupae, thereby killing them and protect the food commodities (Khanikor et al., 2013). Additionally, multiplication of larvae and pupae do not occur inside the grains due to low penetration of essential oil vapors inside the grains, which further protect the grains from infestation of larvae and pupae (Rahman and Schmidt, 1999). Changes in physiology and behavior of insects are also affected by the essential oils which further affect the nervous system. These essential oils also cause reduction in egg laying capacity when it comes in contact with adults as described in the above section. Due to these properties essential oils are also addressed as semiochemicals and have been implemented in IPM (integrated pest management) program in place of those which cause lethality to insects (Rajendran and Sriranjini, 2008). Investigators also reported that in few studies eggs were laid by insects but progeny emergence failed due to the potent components of the oils which penetrate into the eggs via chorion and inhibit the embryonic development (Abdullahi et al., 2011). Failure of egg hatching is also occur when essential oils interferes the physical process of eggs, causing alteration in oxygen and surface tension within the eggs (Abdullahi et al., 2011). Therefore, at beginning of the lifecycle, the population of insects can be reduced by inhibiting their ovipositional behavior. In this paper we reviewed that Mentha oil from different species also caused inhibition of egg laying and progeny emergence of several stored product insects. Therefore, these Mentha oil based ovipositional inhibitors would be useful against insects developing resistance treated with those responsible for lethal toxicity. Such properties of Mentha oil strengthen their recommendation in storage system due to infestation caused by insects. Mentha oils also have ovicidal activity. The mechanism behind ovicidal property is that, through the posterior pole the vapors of essential oil circulate into the eggs and disrupt embryonic development of eggs causing death of the embryo (Credland, 1992). Additionally, essential oils exhibited ovicidal action, may act as neurotoxins when development of nervous system starts (Papachristos and Stamopolos, 2002). It is also reported in this paper that researchers were screened essential oils of Mentha species at different life stage of the insects. Hence, during the insecticide formulation the Mentha oil exhibited potent toxicity at all stages should be considered.

\section{CONCLUSION AND CONSTRAINTS}

The compiled review evidenced that different species of the genus Mentha possessed essential oils which have a wide range of differences in their chemical constituents in samples collected from the different countries. The major components reported in the essential oils of the genus Mentha were pulegone, menthon, menthol, carvone, 1, 8-cineole, limonene, $\beta$-caryophyllene. Menthol is the major derivative product of Mentha species and is widely used in pharmaceuticals, tobacco products, perfumery, aromatherapy, toothpastes, soaps, cosmetics, oral preparations, confectionaries and even in cigarettes. Mentha oil and its derivatives is currently used industrially for various purposes in form of menthol crystals, dementholized oil (DMO), L-menthol, menthone, natural crude Mentha oil, cis 3 hexenol, menthyl acetate, piperitone, limonene, menthofuran, and spearmint terpene. Most commercialized species of Mentha are M. arvensis, M. piperita, and M. spicata. Review also showed that essential oils and chemical constituents from the different species of the genus Mentha are very effective in controlling the fungal and bacterial plant pathogens as well as stored product insects like Callosobruchus and Tribolium species.

Many essential oils have proven their effectiveness as a repellent agent against many storage pests as well as other arthropods including mosquitoes. But directly using essential oils for pest control has some shortcomings viz., volatility, short shelf life and regulatory issues for disbursing it freely in environment. Thus, more insight is needed to overcome 
the barriers of oil use as a pest control agent like, exploring fixative materials for sustained release, application methods and protocols, managing environmental issues, residual phytoxicity, overcoming toxicological and regulatory barriers. One of the promising aspects of use of Mentha oil as grain/food crop protectant is that its favorable mammalian toxicity because its constituents are already used in several products for human consumption. Thus, ecofriendly, biodegradable plant based pesticides which are already in conventional use need less time for their commercial launch in market.

Mentha oil is already used commercially, international products like EcoSMART ${ }^{\circledR}$-ant and roach killer and mosquito repellent uses peppermint oil (1.5\%). It is also one of the constituents in flea shampoos, mosquito repellents topical preparations. Thus when the current human population is now sensitized against use of several harmful xenobiotics as pesticides causing deep environmental and health hazards, switching to plant based alternatives is already on the way and these bio product based industry will strengthen in recent future.

Still there are constraints for Mentha oil and its derivatives as faced by other popular essential oils. High volatility decreases time of protection, thus it needs to be used as impregnated material with some other products. Effects on nontarget microorganisms including pollinators, bees, and natural predators needs to be evaluated. There are bottle necks for its wide use, as not all natural products are always safer and learning from our past, rampant use of chemical without

\section{REFERENCES}

Abbas, K., and Javad, A. (2012). Insecticide activity of essential oils of Mentha longifolia, Pulicaria gnaphalodes and Achillea wilhelmsii against two stored product pests, the flour beetle, Tribolium castaneum, and the cowpea weevil, Callosobruchus maculatus. J. Insect Sci. 12:73. doi: 10.1673/031.012.7301

Abdullahi, N., Mojeed, Q., and Oyeyi, T. I. (2011). Studies on the efficacy of Vittallaria paradoxa seed oil on the oviposition, hatchability of eggs and emergence of Callosobruchus maculatus (F.) (Coleopteran: Bruchidae) on treated cowpea seed. J. Entomol. 8, 391-3971-7.

Aghel, N., Yamini, Y., Hadjiakhoondi, A., and Pourmortazavi, S. M. (2004). Supercritical carbon dioxide extraction of Mentha pulegium L. essential oil. Talanta 62, 407-411. doi: 10.1016/j.talanta.2003.08.011

Agnihotri, V. K., Agarwal, S. G., Dhar, P. L., Thappa Baleshwar, R. K., Kapahi, B. K., Saxena, R. K., et al. (2005). Essential oil composition of Mentha pulegium L. growing wild in the north-western Himalayas India. Flavour Fragr. J. 20, 607-610. doi: 10.1002/ffj.1497

Agrios, G. N. (2005). Plant Pathology, 5th Edn. Oxford: Elsevier Academic Press.

Ait-Ouazzou, A., Lorán, S., Arakrak, A., Laglaoui, A., Rota, C., Herrera, A., et al. (2011). Evaluation of the chemical composition and antimicrobial activity of Mentha pulegium, Juniperus phoenicea, and Cyperus longus essential oils from Morocco. Food Res. Int. 45, 313-319. doi: 10.1016/j.foodres.2011. 09.004

Al-Sarar, A. S., Hussein, H. I., and Abobakr, Y. (2014). Fumigant toxicity and antiacetylcholinesterase activity of Saudi Mentha longifolia and Lavandula dentata species against Callosobruchus maculatus (F.) (Coleoptera: Bruchidae). Turk. J. Entomol. 38, 11-18.

Bassolé, I. H. N., Lamien-Meda, A., Bayala, B., Tirogo, S., Franz, C., Novak, J., et al. (2010). Composition and antimicrobial activities of Lippia multiflora Moldenke, Mentha $x$ piperita L. and Ocimum basilicum L. essential oils and their major monoterpene alcohols alone and in combination. Molecules 15, 7825-7839. doi: 10.3390/molecules15117825 assessing its long term effects would be a mistake. Thus, natural products must be scientifically validated for their long term use and release. Issues regarding its formulation like proper identification, pressure on natural resources, phytotoxicity, mammalian toxicity, standardization of product, registration and regulation have to be taken care of for its overall commercialization.

Further most promising natural products can pave a way for their synthetic manufacture which will pose less pressure on natural resources and will be economically feasible for their wide spread use as a pesticide. Thus, antimicrobial and insecticidal properties of essential oils of Mentha species offer the prospect of using them as natural pesticides and they can have market niches with a commercial value. Finally, a systematic and gradual approach for embracing natural products against several pests of agriculture without jeopardizing commercial, social interest is need of the day for a healthy sustainable environment in future.

\section{AUTHOR CONTRIBUTIONS}

AP contributed as co-author in reviewing the literature, compiling the information, preparing the review draft, and revising the manuscript. PS guided co-author to outline the sections, compile the manuscript, critically reviewed and revised the manuscript, and restructured the entire manuscript with significant contribution to shape the manuscript for the final version.

Beghidja, N., Bouslimani, N., Benayache, F., Benayache, S., and Chalchat, J. (2007). Composition of the oils from Mentha pulegium grown in different areas of the East of Algeria. Chem. Nat. Compd. 43, 481-483. doi: 10.1007/s10600-0070170-6

Beyki, M., Zhaveh, S., Khalili, S. T., Rahmani-Cherati, T., Abollahi, A., Bayat, M., et al. (2014). Encapsulation of Mentha piperita essential oils in chitosancinnamic acid nanogel with enhanced antimicrobial activity against Aspergillus flavus. Ind. Crop Prod. 54, 310-319. doi: 10.1016/j.indcrop.2014.01.033

Bouchra, C., Achouri, M., Hassani, L. M., and Hmamouchi, M. (2003). Chemical composition and antifungal activity of essential oils of seven Moroccan Labiatae against Botrytis cinerea Pers: Fr. J. Ethanopharmacol. 89, 165-169. doi: 10.1016/ S0378-8741(03)00275-7

Chang, K. F., Ahmed, H. U., Hwang, S. F., Gossen, B. D., Strelkov, S. E., Blade, S. F., et al. (2007). Sensitivity of field populations of Ascochyta rabiei to chlorothalonil, mancozeb, and pyraclostrobin fungicides, and effects of strobilurin fungicides on the progress of Ascochyta blight of chickpea. Can. J. Plant Sci. 87, 937-944. doi: 10.4141/CJPS0701

Chaudhry, M. Q. (1997). A review of the mechanisms involved in the action of phosphine as an insecticide and phosphine resistance in stored-product insects. Pest Manag. Sci. 49, 213-228. doi: 10.1002/(SICI)1096-9063(199703)49:3<213:: AID-PS516>3.0.CO;2-\#

Cherrat, L., Espina, L., Bakkali, M., Pagán, R., and Laglaoui, A. (2014). Chemical composition, antioxidant and antimicrobial properties of Mentha pulegium: Lavandula stoechas and Satureja calamintha Scheele essential oils and an evaluation of their bactericidal effect in combined processes. Innov. Food Sci. Emerg. Technol. 22, 221-229. doi: 10.1016/j.ifset.2013.12.016

Clark, R. K., and Menory, R. C. (1980). Environmental effects or peppermint (Mentha piperita). Aust. J. Plant Physiol. 7, 685-692. doi: 10.1071/PP9800685

Cox, S. D., Mann, C. M. I., Markham, J. L., Bell, H. C., Gustafson, J. E., Warmington, J. R., et al. (2000). The mode of antimicrobial action of the essential oil of Melaleuca alternifolia (tea tree oil). J. Appl. Microbiol. 88, 170-175. doi: 10.1046/j.1365-2672.2000.00943.x 
Credland, P. (1992). The structure of bruchid eggs may explain the ovicidal effect of oils. J. Stored Prod. Res. 28, 1-9. doi: 10.1016/0022-474X(92)90025-L

Cuppels, D. A., and Elmhirst, J. (1999). Disease development and changes in the natural Pseudomonas syringae pv. tomato populations on field tomato plants. Plant Dis. 83, 759-764. doi: 10.1094/PDIS.1999.83.8.759

Derbalah, A. S., and Ahmed, S. I. (2011). Oil and powder of spearmint as an alternative to Sitophilus oryzae chemical control of wheat grains. J. Plant Prot. Res. 51, 145-150. doi: 10.2478/v10045-011-0025-9

Derwich, E., Benziane, Z., and Boukir, A. (2010). Antibacterial activity and chemical composition of the leaf essential oil of Mentha rotundifolia from Morocco. Electron. J. Environ. Agric. Food Chem. 9, 19-28.

Díaz-Maroto, M. C., Castillo, N., Castro-Vázquez, L., González-Viñnas, M. Á, and Pérez-Coello, M. S. (2007). Volatile composition and olfactory profile of pennyroyal (Mentha pulegium) plants. Flavour Fragr. J. 22, 114-118. doi: 10. $1002 /$ ffj. 1766

Diop, S. M., Guèye, M. T., Ndiaye, I., Ndiaye, E. B., Diop, M. B., Heuskin, S., et al. (2016). Chemical composition of essential oils and floral waters of Mentha longifolia (L.) Huds. from Senegal. Am. J. Essent. Oils Nat. Prod. 4, 46-49.

Djenane, D., Aïder, M., Yangüela, J., Idir, L., Gomez, D., and Roncales, P. (2012). Antioxidant and antibacterial effects of Lavandula and Mentha essential oils in minced beef inoculated with E. coli $\mathrm{O} 157: \mathrm{H} 7$ and S. aureus during storage at abuse refrigeration temperature. Meat Sci. 92, 667-674. doi: 10.1016/j.meatsci. 2012.06.019

Djordjevic, M., Djordjevic, O., Djordjevic, R., Mijatovic, M., Kostic, M., Todorovic, G., et al. (2013). Alternative approach in control of tomato pathogen by using essential oils In vitro. Pak. J. Bot. 45, 1069-1072.

Dorman, H. J. D., and Deans, S. G. (2000). Antibacterial agents from plants: antibacterial activity of plant volatile oils. J. Appl. Microbiol. 88, 308-316. doi: 10.1046/j.1365-2672.2000.00969

Dorman, H. J. D., Peltoketo, A., Hiltunen, R., and Tikkanen, M. J. (2003). Characterisation of the antioxidant properties of de-odourised aqueous extracts from selected Lamiaceae herbs. Food Chem. 83, 255-262. doi: 10.1016/S03088146(03)00088-8

Džamić, A. M., Soković, M. D., Ristić, M. S., Novaković, M., Jovanović, S. G., Tešević, V., et al. (2010). Antifungal and antioxidant activity of Mentha longifolia (L.) Hudson (Lamiaceae) essential oil. Bot. Serb. 34, 57-61.

El-Ghorab, A. H. (2006). The chemical composition of Mentha pulegium L. essential oil from Egypt and its antioxidant activity. J. Essent. Oil Bear. Plants 9, 183-195. doi: 10.1080/0972060X.2006.10643491

Eliopoulos, P. A., Hassiotis, C. N., and Andreadis, S. S. (2015). Fumigant toxicity of essential oils from basil and spearmint against two major pyralid pests of stored products. J. Econ. Entomol. 108, 805-810. doi: 10.1093/jee/tov029

Figueiredo, A. C., Barroso, J. G., Pedro, L. G., and Scheffer, J. C. (2008). Factors affecting secondary metabolite production in plants: volatile components and essential oils. Flavour Fragr. J. 23, 213-226. doi: 10.1002/ffj.1875

Franz, A. R., Knaak, N., and Fiuza, L. M. (2011). Toxic effects of essential plant oils in adult Sitophilus oryzae (Linnaeus) (Coleoptera, Curculionidae). Rev. Bras. Entomol. 55, 116-120. doi: 10.1590/S0085-56262011000100018

Goudjil, M. B., Ladjel, S., Zighmi, S., Hammoya, F., Bensaci, M. B., Mehani, M., et al. (2016). Bioactivity of Laurus Nobilis and Mentha Piperita essential oils on some phytopathogenic fungi )in vitro assay) J. Mater. Environ. Sci. 7, 4525-4533.

Griffin, S. G., Markham, J. L., and Leach, D. N. (2000). An agar dilution method for the determination of the minimum inhibitory concentration of essential oils. J. Essent. Oil Res. 12, 249-255.

Gulluce, M., Sahin, F., Sokmen, M., Ozer, H., Daferera, D., Sokmen, A., et al. (2007). Antimicrobial and antioxidant properties of the essential oils and methanol extract from Mentha longifolia L. ssp. longifolia. Food Chem. 103, 1449-1456. doi: 10.1016/j.foodchem.2006.10.061

Gupta, A., Sharma, S., and Naik, S. N. (2011). Biopesticidal value of selected essential oils against pathogenic fungus, termites, and nematodes. Int. Biodeterior. Biodegradation 65, 703-707. doi: 10.1016/j.ibiod.2010.11.018

Gurkan, B., and Fedai, E. (2013). Evaluation of some essential oils and their major components against mushroom scatopsid flies as fumigants. Fresenius Environ. Bull. 22, 3170-3178.

Hajlaoui, H., Ben, A. F., Snoussi, M., Noumi, E., and Bakhrouf, A. (2010). Effect of Mentha longifolia L. ssp longifolia essential oil on the morphology of four pathogenic bacteria visualized by atomic force microscopy. Afr. J. Microbiol. Res. 4, 1122-1127.

Hajlaoui, H., Snoussi, M., Jannet, H. B., Mighri, Z., and Bakhrouf, A. (2008). Comparison of chemical composition and antimicrobial activities of Mentha longifolia L. ssp. longifolia essential oil from two Tunisian localities (Gabes and Sidi Bouzid). Ann. Mirobiol. 58, 513-520. doi: 10.1007/BF03175551

Hajlaoui, H., Trabelsi, N., Noumi, E., Snoussi, M., Fallah, H., Ksouri, R., et al. (2009). Biological activities of the essential oils and methanol extract of tow cultivated mint species (Mentha longifolia and Mentha pulegium) used in the Tunisian folkloric medicine. World J. Microbiol. Biotechnol. 25, 2227-2238. doi: 10.1007/s11274-009-0130-3

Halit, C., Cem, K. O., and Ayhan, G. (2012). Fumigant toxicity of different Mentha species against granary weevil [Sitophilus granarius L. (Coleoptera: Curculionidae)]. Turk. J. Entomol. 36, 255-263.

Harley, R. M., Atkins, S., Budantsev, A. L., Cantino, P. D., Conn Renée, J., and Grayer Madeline, M. (2004). "Labiatae," in The Families and Genera of Vascular Plants, ed. K. Kubitzki (Berlin: Springer-Verlag), 167-275.

Hussain, A. I., Anwar, F., Nigam, P., Ashraf, M., and Gilani, A. (2010a). Seasonal variation in content, chemical composition and antimicrobial and cytotoxic activities of essential oils from four Mentha species. J. Sci. Food Agric. 90, 1827-1836. doi: 10.1002/jsfa.4021

Hussain, A. I., Anwar, F., Shahid, M., Ashraf, M., and Przybylski, R. (2010b). Chemical composition, anticoidant and antimicrobial activities of essential oil of spearmint (Mentha spicata L.) from Pakistan. J. Essent. Oil Res. 22, 78-84. doi: $10.1080 / 10412905.2010 .9700269$

Iacobellis, N. S., Cantore, P. L., Capasso, F., and Senatore, F. (2005). Antibacterial activity of Cuminum cyminum L. and Carum carvi L. essential oils. J. Agric. Food Chem. 53, 57-61. doi: 10.1021/jf0487351

Irfan, A., Isa, T., and Oender, C. (2009). Toxicity of essential oil vapours obtained from several plants species against the granary weevil, Sitophilus granarius (L.). Fresenius Environ. Bull. 18, 1717-1722.

Iscan, G., Kirimer, N., Kurkcuoglu, M., Baser, K. H., and Demirci, F. (2002). Antimicrobial screening of Mentha piperita essential oils. J. Agric. Food Chem. 50, 3943-3946. doi: 10.1021/jf011476k

Kadoglidou, K., Lagopodi, A., Karamanoli, K., Vokou, D., Bardas, G. A., Menexes, G., et al. (2011). Inhibitory and stimulatory effects of essential oils and individual monoterpenoids on growth and sporulation of four soil-borne fungal isolates of Aspergillus terreus, Fusarium oxysporum, Penicillium expansum, and Verticillium dahliae. Eur. J. Plant Pathol. 130, 297-309. doi: 10.1007/s10658011-9754-x

Kamkar, A., Javan, A. J., Asadi, F., and Kamalinejad, M. (2010). The antioxidative effect of Iranian Mentha pulegium extracts and essential oil in sunflower oil. Food Chem. Toxicol. 48, 1796-1800. doi: 10.1016/j.fct.2010.04.003

Kedia, A., Bhanu, P., and Mishra, P. K. (2014). Antifungal, antiaflatoxigenic, and insecticidal efficacy of spearmint (Mentha spicata L.) essential oil. Int. Biodeterior. Biodegradation 89, 29-36. doi: 10.1016/j.ibiod.2013.10.027

Khanikor, B., Parida, P., Yadav, R. N. S., and Bora, D. (2013). Comparative mode of action of some terpene compounds against octopamine receptor and acetyl cholinesterase of mosquito and human system by the help of homology modeling and Docking studies. J. Appl. Pharm. Sci. 3, 6-12. doi: 10.7324/JAPS. 2013.30202

Kizil, S., Nesrin, H. A., Tolan, V., Kilinc, E., and Yuksel, U. (2010). Mineral content, essential oil components and biological activity of two Mentha species (M. piperita L., M. spicata L.). Turk. J. Field Crops 15, 148-153.

Kokkini, S., Karousou, T. R., and Lanaras, A. (1995). Essential oils of spearmint (Carvone-rich) plants from the Island of Crete (Greece). Biochem. Syst. Ecol. 23, 425-430. doi: 10.1016/0305-1978(95)00021-L

Kokoskova, B., Pouvova, D., and Pavela, R. (2011). Effectiveness of plant essential oils against Erwinia amylovora, Pseudomonas syringae pv. syringae and associated saprophytic bacteria on/in host plants. J. Plant Pathol. 93, 133-139.

Koliopoulos, G., Pitarokili, D., Kioulos, E., Michaelakis, A., and Tzakou, O. (2010). Chemical composition and larvicidal evaluation of Mentha, Salvia, and Melissa essential oils against the West Nile virus mosquito Culex pipiens. Parasitol. Res. 107, 327-335. doi: 10.1007/s00436-010-1865-3

Koschiera, E. H., Sedya, K. A., and Novak, J. (2002). Influence of plant volatiles on feeding damage caused by the onion thrips Thrips tabaci. Crop Prot. 21, 419-425. doi: 10.1016/S0261-2194(01)00124-7 
Kostyukovsky, M., Rafaeli, A., Gileadi, C., Demchenko, N., and Shaaya, E. (2002). Activation of octopaminergic receptors by essential oil constituents isolated from aromatic plants: possible mode of action against insectpests. Pest Manag. Sci. 58, 1101-1106. doi: 10.1002/ps.548

Kumar, A., Shukla, R., and Singh, P. (2009). Use of essential oil from Mentha arvensis L. to control storage moulds and insects in stored chickpea. J. Sci. Food Agric. 89, 2643-2649. doi: 10.1002/jsfa.3768

Kumar, P., Mishra, S., Malik, A., and Satya, S. (2010). Insecticidal properties of Mentha species: a review. Ind. Crop Res. 34, 802-817. doi: 10.3390/ molecules 20058605

Li, Y., Fabiano-Tixier, A. S., Abert, M., and Chemat, V. F. (2013). Solvent free microwave extraction of bioactive compound provides a tool for green analytical chemistry. Trends Anal. Chem. 47, 1-11. doi: 10.1016/j.trac.2013.02. 007

Lopez-Reyes, J. G., Spadaro, D., Gullino, M. L., and Garibaldi, A. (2010). Efficacy of plant essential oils on postharvest control of rot caused by fungi on four cultivars of apples in vivo. Flavour Fragr. J. 25, 171-177. doi: 10.1002/ffj.1989

Lopez-Reyes, J. G., Spadaro, D., Prelle, A., Garibaldi, A., and Gullino, M. L. (2013). Efficacy of plant essential oils on postharvest control of rots caused by fungi on different stone fruits in vivo. J. Food Prot. 76, 631-639. doi: 10.4315/0362-028X. JFP- $12-342$

Lorenzo, D., Paz, D., Dellacassa, E., Davies, P., Vila, R., and Cañigueral, S. (2002). Essential oils of Mentha pulegium and Mentha rotundifolia from Uruguay. Braz. Arch. Biol. Technol. 45, 519-524. doi: 10.1590/S1516-89132002000600016

Louws, F. J., Wilson, M., Campbell, H. L., Cuppels, D. A., Jones, J. B., Shoemaker, P. B., et al. (2001). Field control of bacterial spot and bacterial speck of tomato using a plant activator. Plant Dis. 85, 481-488. doi: 10.1094/PDIS.2001.85.5.481

Lubbe, A., and Verpoorte, R. (2011). Cultivation of medicinal and aromatic plants for specialty industrial materials. Ind. Crops Prod. 34, 785-801. doi: 10.1016/j. indcrop.2011.01.019

Mahboubi, M., and Haghi, G. (2008). Antimicrobial activity and chemical composition of Mentha pulegium L. essential oil. J. Ethanopharmacol. 119, 325-327. doi: 10.1016/j.jep.2008.07.023

Marco, G. M., and Stall, R. E. (1983). Control of bacterial spot of pepper initiated by strains of Xanthomonas campestris pv. vesicatoria that differ in sensitivity to copper. Plant Dis. 67, 779-781. doi: 10.1094/PD-67-779

Marotti, M., Piccaglia, R., Giovanelli, E., Deans, S. G., and Eaglesham, E. (1994). Effects of planting time and mineral fertilization on peppermint (Mentha $x$ piperita 1.) essential oil composition and its biological activity. Flavour Frag. J. 9, 125-129. doi: 10.1002/ffj.2730090307

Marzouk, B., Ben Hadj Fredj, M., and Chraief, I. (2008). Chemical composition and antimicrobial activity of essential oils from Tunisian Mentha pulegium L. J. Food Agric. Environ. 6, 78-82.

Mata, A. T., Proenca, C., Ferreira, A. R., Serralheiro, M. L. M., Nogueira, J. M. F., and Araujo, M. E. M. (2007). Antioxidant and antiacetylcholinesterase activities of five plants used as Portuguese food species. Food Chem. 103, 778-786. doi: 10.1016/j.foodchem.2006.09.017

McKay, D. L., and Blumberg, J. B. (2006). A review of the bioactivity and potential health benefits of peppermint tea (Mentha piperita L.). Phytother. Res. 20, 619-633. doi: 10.1002/ptr.1936

Mehani, M., Segni, L., Terzi, V., Morcia, C., Ghizzoni, R., Goudjil, M. B., et al. (2015). Antibacterial, antifungal activity and chemical composition study of essential oil of Mentha pepirita from the south Algerian. Der Pharma Chemica 7, 382-387.

Mimica-Dukic, N., Bozin, B., Soković, M., Mihajlović, B., and Matavulj, M. (2003). Antimicrobial and antioxidant activities of three Mentha species essential oils. Planta Med. 69, 413-419. doi: 10.1055/s-2003-39704

Mishra, A. K., Pandey, A. K., Singh, P., and Tripathi, N. N. (2013). Mycoparasites of Ganoderma lucidum and their botanical management. Proc. Natl. Acad. Sci. India Sec. B Biol. Sci. 83, 119-123.

Mishra, B. B., Tripathi, S. P., and Tripathi, C. P. M. (2014). Sub-lethal activity of plant volatile essential oils in management of red flour beetle Tribolium castaneum (Coleoptera: Tenebrionidae). J. Essent. Oil Bear. Plants 17, 12111218. doi: 10.1080/0972060X.2014.961038

Miyazawa, M., Watanabe, H., Umemoto, K., and Kameoka, H. (1998). Inhibition of acetylcholinesterase activity by essential oils of Mentha Species. J. Agric. Food Chem. 46, 3431-3434. doi: 10.1021/jf9707041
Mkaddem, M., Bouajila, J., Ennajar, M., Lebrihi, A., Mathieu, F., and Romdhane, M. (2009). Chemical composition and antimicrobial and antioxidant activities of Mentha (longifolia L. and viridis) essential oils. J. Food Sci. 74, M358-M363. doi: $10.1111 / \mathrm{j} .1750-3841.2009 .01272 . \mathrm{x}$

Mkaddem, M., Bousaid, M., and Ben Fadhel, N. (2007). Variability of volatiles in Tunisian Mentha pulegium L. (Lamiaceae). J. Essent. Oil Res. 19, 211-215. doi: 10.1080/10412905.2007.9699263

Moghaddam, M., Pourbaige, M., Tabar, H. K., Farhadi, N., and Hosseini, S. M. A. (2013). Composition and antifungal activity of peppermint (Mentha piperita) essential oil from Iran. J. Essent. Oil Bear. Plants 16, 506-512. doi: 10.1080/ 0972060X.2013.813265

Mohamed, M. I. E., and Abdelgaleil, S. A. M. (2008). Chemical composition and insecticidal potential of essential oils from Egyptian plants against Sitophilus oryzae (L.) (Coleoptera: Curculionidae) and Tribolium castaneum (Herbst) (Coleoptera: Tenebrionidae). Appl. Entomol. Zool. 43, 599-607. doi: 10.1303/ aez.2008.599

Moreno, L., Bello, R., Primo-Yúfera, E., and Esplugues, J. (2002). Pharmacological properties of the methanol extract from Mentha suaveolens Ehrh. Phytother. Res. 16, 10-13. doi: 10.1002/ptr.744

Müller-Riebau, F., Berger, B., and Yegen, O. (1995). Chemical composition and fungitoxic properties to phytopathogenic fungi of essential oils of selected aromatic plants growing wild in Turkey. J. Agric. Food Chem. 43, 2262-2266. doi: $10.1021 /$ jf00056a055

Müller-Riebau, F. J., Berger, B. M., Yegen, O., and Cakir, C. (1997). Seasonal variations in the chemical compositions of essential oils of selected aromatic plants growing wild in Turkey. J. Agric. Food Chem. 45, 4821-4825. doi: 10. 1021/jf970110y

Nubia, S. V., Oliveira, F., Romero, C., Matos, C., and Helena, C. (2016). Fumigation toxicity of essential oils against Rhyzopertha dominica (f.) in stored maize grain. Revista Caatinga 29, 435-440. doi: 10.1590/1983-21252016v29n220rc

Odeyemi, O. O., Masika, P., and Afolayan, A. J. (2008). Insecticidal activities of essential oil from the leaves of Mentha longifolia L. subsp. capensis against Sitophilus zeamais (Motschulsky) (Coleoptera: Curculionidae). Afr. Entomol. 16, 220-225. doi: 10.4001/1021-3589-16.2.220

Oudhia, P. (2003). Traditional and Medicinal Knowledge about Pudina Mentha sp. Family: Labiatae) in Chhattisgarh, India. Botanical. Available at: http:// botanical.com

Oussalah, M., Caillet, S., Saucier, L., and Lacroix, M. (2006). Antimicrobial effects of selected plant essential oils on the growth of a Pseudomonas putida strain isolated from meat. Meat Sci. 73, 236-244. doi: 10.1016/j.meatsci.2005.11.019

Oyedeji, O. A., and Afolayan, A. J. (2006). Chemical composition and antibacterial activity of the essential oil isolated from South African Mentha longifolia (L.) subsp. capensis (Thunb.) Briq. J. Essent. Oil Res. 18, 57-59.

Pandey, A. K., Kumar, P., Singh, P., Tripathi, N. N., and Bhajpai, V. K. (2017). Essential oils: Source of antimicrobial and food preservative properties. Front. Microbiol. 7:2161. doi: 10.3389/fmicb.2016.02161

Pandey, A. K., Singh, P., Palni, U. T., and Tripathi, N. N. (2011). Use of essential oils of aromatic plants for the management of pigeon pea infestation by pulse bruchids during storage. Int. J. Agric. Technol. 7, 1615-1624.

Pandey, A. K., Singh, P., Palni, U. T., and Tripathi, N. N. (2013). Application of Chenopodium ambrosioides Linn. essential oil as botanical fungicide for the management of fungal deterioration in pulse. Biol. Agric. Hortic. 29, 197-208. doi: $10.1080 / 01448765.2013 .822828$

Pandey, A. K., and Tripathi, N. N. (2011). Post- harvest fungal and insect deterioration of pigeon pea seeds and their management by plant volatiles. J. Indian Bot. Soc. 90, 326-331.

Papachristos, D. P., and Stamopolos, D. C. (2002). Toxicity of vapours of three essential oils to immature stages of Acanthoscelides obtectus (Say) (Coleoptera: Bruchidae). J. Stored Prod. Res. 38, 365-373. doi: 10.1016/S0022-474X(01) 00038-8

Paranagama, P. A., Abeysekera, K. H. T., Abeywickrama, K., and Nugaliyadde, L. (2003). Fungicidal and anti-aflatoxigenic effects of the essential oil of Cymbopogon citratus (DC.) Stapf. (lemongrass) against Aspergillus flavus Link. isolated from stored rice. Lett. Appl. Microbiol. 37, 86-90. doi: 10.1046/j.1472765X.2003.01351.X

Pare, P. W., and Tumlinson, J. H. (1999). Plant volatiles as a defense against insect herbivores. Plant Physiol. 121, 325-331. doi: 10.1104/pp.121.2.325 
Perez Raya, M. D., Utrilla, S. M. P., Navarro, M. C., and Jim Cnez, J. (1990). CNS Activity of Mentha rotundgolia and Mentha longifolia Rats? Phytother. Res. 4, 232-234. doi: 10.1002/ptr.3037

Perricone, M., Arace, E., Corbo, M. R., Sinigaglia, M., and Bevilacqu, A. (2015). Bioactivity of essential oils: a review on their interaction with food components. Front. Microbiol. 6:76. doi: 10.3389/fmicb.2015.00076

Petrakis, E. A., Kimbaris, A. C., Pappas, C. S., Tarantilis, P. A., and Polissiou, M. G. (2009). Quantitative determination of pulegone in pennyroyal oil by FT-IR spectroscopy. J. Agric. Food Chem. 57, 10044-10048. doi: 10.1021/jf9026052

Picollo, M. I., Toloza, A. C., Mougabure, C. G., Zygadlo, J., and Zerba, E. (2008). Anticholinesterase and pediculicidal activities of monoterpenoids. Fitoterapia 79, 271-278. doi: 10.1016/j.fitote.2008.01.005

Price, P. P., Purvis, M. A., Cai, G., Padgett, G. B., Robertson, C. L., Schneider, R. W., et al. (2015). Fungicide resistance in Cercospora kikuchii, a soybean pathogen. Plant Dis. 99, 1596-1603. doi: 10.1094/PDIS-07-14-0782-RE

Rahman, M. M., and Schmidt, G. H. (1999). Effect of Acorus calamus (L.) (Araceae) essential oil vapours from various origins on Callosobruchus phaseoli (Gyllenhal) (Coleoptera: Bruchidae). J. Stored Prod. Res. 35, 285-295. doi: 10. 1016/S0022-474X(99)00012-0

Rajendran, S., and Sriranjini, V. (2008). Plant products as fumigants for storedproduct insect control. J. Stored Prod. Res. 44, 126-135. doi: 10.1016/j.jspr.2007. 08.003

Regnier, T., Combrinck, S., Veldman, W., and Du Plooy, W. (2014). Application of essential oils as multi-target fungicides for the control of Geotrichum citriaurantii and other postharvest pathogens of citrus. Ind. Crop Prod. 61, 151-159. doi: 10.1016/j.indcrop.2014.05.052

Reis-Vasco, E. M. C., Coelho, J. A. P., and Palavra, A. M. F. (1999). Comparison of pennyroyal oils obtained by supercritical $\mathrm{CO} 2$ extraction and hydrodistillation. Flavour Fragr. J. 14, 156-160. doi: 10.1002/(SICI)1099-1026(199905/06)14: $3<156:$ :AID-FFJ793>3.0.CO;2-J

Rezende, D. A. C. S., Souza, R. V., Magalhães, M. L., Caetano, A. R. S., Carvalho, M. S. S., de Souza, E. C., et al. (2017). Characterization of the biological potential of the essential oils from five species of medicinal plants. Am. J. Plant Sci. 8, 154-170. doi: 10.4236/ajps.2017.82012

Rhouma, A., Daoud, H. B., Ghanmi, S., Salah, H. B., Romdhane, M., and Demak, M. (2009). Antimicrobial activities of leaf extracts of Pistacia and Schinus species against some plant pathogenic fungi and bacteria. J. Plant Pathol. 91, 339-345.

Riahi, L., Elferchichi, M., Ghazghazi, H., Jebali, J., Ziadi, S., Aouadhi, C., et al. (2013). Phytochemistry, antioxidant and antimicrobial activities of the essential oils of Mentha rotundifolia L. in Tunisia. Ind. Crops Prod. 43, 883-889. doi: 10.1016/j.indcrop.2013.06.032

Rodrigues, L., Póvoa, O., Teixeira, G., Figueiredo, A. C., Moldão, M., and Monteiro, A. (2013). Trichomes micromorphology and essential oil variation at different developmental stages of cultivated and wild growing Mentha pulegium L. populations from Portugal. Ind. Crop Prod. 43, 692-700. doi: 10.1016/j. indcrop.2012.07.061

Rohloff, J., Dragland, S., Mordal, R., and Iversen, T. (2005). Effect of harvest time and drying method on biomass production, essential oil yield, and quality of peppermint (Mentha $\times$ piperita L.). J. Agric. Food Chem. 53, 4143-4148. doi: $10.1021 /$ jf047998s

Saharkhiz, M. J., Motamedi, M., Zomorodian, K., Pakshir, K., Miri, R., and Hemyari, K. (2012). Chemical composition, antifungal and antibiofilm activities of the essential oil of Mentha piperita L. ISRN Pharm. 2012:718645. doi: 10.5402/ $2012 / 718645$

Samarasekera, R., Weerasinghe, I. S., and Hemalal, K. D. P. (2008). Insecticidal activity of menthol derivatives against mosquitoes. Pest Manag. Sci. 64, 290-295. doi: $10.1002 /$ ps. 1516

Sam-Daliri, H., Mousavi, Z., Naderi, N., and Asgarpanah, J. (2016). Chemical composition and analgesic activity of the essential oil of Mentha mozaffarianii jamzad leaves. Bulg. Chem. Commun. 48, 641-645.

Saroukolai, A. T., Nouri-Ganbalani, G., and Rafiee-Dastjerdi, H. (2014). Antifeedant activity and toxicity of some plant essential oils to colorado potato beetle, Leptinotarsa decemlineata Say (Coleoptera: Chrysomelidae). Plant Prot. Sci. 50, 207-216. doi: 10.17221/9/2014-PPS

Shaaya, E., and Kostyukovsky, M. (2006). Essential oils: potency against stored product insects and mode of action. Stewart Posthar. Rev. 2, 1-6. doi: 10.5650/ jos.ess 15094
Sharifi-Rad, M., Varoni, E. M., Salehi, B., Sharifi-Rad, J., Matthews, K. R., Ayatollahi, S. A., et al. (2017). Plants of the genus Zingiber as a source of bioactive phytochemicals: from tradition to pharmacy. Molecules 22:E2145. doi: 10.3390/molecules22122145

Sharifi-Rad, J., Sureda, A., Tenore, G. C., Daglia, M., Sharifi-Rad, M., Valussi, M., et al. (2017). Biological activities of essential oils: from plant chemoecology to traditional healing systems. Molecules 22:E70. doi: 10.3390/molecules22010070

Sharifi-Rad, R., Nazaruk, J., Polito, L., Morais-Braga, M. F. B., Rocha, J. E., MeloCoutinho, H. D., et al. (2018). Matricaria genus as a source of antimicrobial agents: from farm to pharmacy and food applications. Microbiol. Res. 215, 76-88. doi: 10.1016/j.micres.2018.06.010

Sharma, V., Sharma, N., Singh, H., Srivastava, D. K., Pathania, V., Singh, B., et al. (2009). Comparative account on GC-MS analysis of Mentha arvensis L. corn mint. From three different locations of North India. Int. J. Drug Dev. Res. 21, $1-9$.

Singh, P. (2010). Advances in control of post-harvest diseases of papaya fruit-a Review. Agric. Rev. 31, 194-202.

Singh, P., Pandey, A. K., and Tripathi, N. N. (2012). Essential oils: a renewable source for the management of stored product insects-A review. Agric. Rev. 33, 226-236.

Sivropoulou, A., Kokkini, S., Lanaras, T., and Arsenakis, M. (1995). Antimicrobial activity of mint essential oils. J. Agric. Food Chem. 43, 2384-2388. doi: 10.1021/ jf00057a013

Snoussi, M., Noumi, E., Trabelsi, N., Flamini, G., Papetti, A., and De Feo, V. (2015). Mentha spicata essential oil: chemical composition, antioxidant and antibacterial activities against planktonic and biofilm cultures of Vibrio spp. Strains. Molecules 2, 14402-14424. doi: 10.3390/molecules200814402

Sokovic, M., and van Griensven, L. J. L. D. (2006). Antimicrobial activity of essential oils and their components against the three major pathogens of the cultivated button mushroom, Agaricus bisporus. Eur. J. Plant Pathol. 116, 211-224. doi: 10.1007/s10658-006-9053-0

Soković, M. D., Vukojević, J., Marin, P. D., Brkić, D. D., Vajs, V., and van Griensven, L. J. L. D. (2009). Chemical composition of essential oils of Thymus and Mentha Species and their antifungal activities. Molecules 14, 238-249. doi: $10.3390 /$ molecules 14010238

Soltani, J., and Aliabadi, A. A. (2012). Antibacterial effects of several plant extracts and essential oils on Xanthomonas arboricola pv. juglandis in vitro. J. Essent. Oil Bear. Plants 16, 461-468.

Somaye, A. (2010). Reducing insects contaminations through stored foodstuffs by use of packaging and repellency essential oils. Not. Bot. Horti Agrobot. Cluj Napoca 38, 21-24.

Sonker, N., Pandey, A. K., and Singh, P. (2015). Efficiency of Artemisia nilagirica (Clarke) Pamp. essential oil as a mycotoxicant against postharvest mycobiota of table grapes. J. Sci. Food Agric. 95, 1932-1939. doi: 10.1002/jsfa.6901

Stall, R. E., and Thayer, P. L. (1962). Streptomycin resistance of the bacterial spot pathogen and control with streptomycin. Plant Dis. Rep. 46, 389-392. doi: 10.1094/MPMI-01-18-0007-R

Stoyanova, A., Georgie, V., Kula, J., and Majda, T. (2005). Chemical composition of the essential oil of Mentha pulegium from Bulgaria. J. Essent. Oil Res. 17, 475-477. doi: 10.1080/10412905.2005.9698968

Sun, Z., Wang, H., Wang, J., Zhou, L., and Yang, P. (2014). Chemical composition and anti-inflammatory, cytotoxic and antioxidant activities of essential oil from leaves of Mentha piperita Grown in China. PLoS One 9:e114767. doi: 10.1371/ journal.pone.0114767

Sutour, S., Bradesi, P., Rocca-Serra, D., Casanova, J., and Félix, T. (2008). Chemical composition and antibacterial activity of the essential oil from Mentha suaveolens ssp. insularis (Req.) Greuter. Flavour Fragr. J. 23, 107-114. doi: $10.1002 / \mathrm{ffj} .1863$

Teixeira, B., Marques, A., Ramos, C., Batista, I., Serrano, C., Matos, O., et al. (2012). European pennyroyal (Mentha pulegium) from portugal: chemical composition of essential oil and antioxidant and antimicrobial properties of extracts and essential oil. Ind. Crop Prod. 36, 81-87. doi: 10.1016/j.indcrop.2011.08.011

Trombetta, D., Castelli, F., Sarpietro, M. G., Venuti, V., Cristani, M., Daniele, C., et al. (2005). Mechanisms of antibacterial action of three monoterpenes. Antimicrob. Agents Chemother. 49, 2474-2478. doi: 10.1128/AAC.49.6.24742478.2005

Tyagi, A. K., and Malik, A. (2011). Antimicrobial potential and chemical composition of Mentha piperita oil in liquid and vapour phase against food 
spoiling microorganisms. Food Control 22, 1707-1714. doi: 10.1016/j.foodcont. 2011.04.002

Vasinauskienë, M., Radušiene, J., Zitikaitë, I., and Survilienë, E. (2006). Antibacterial activities of essential oils from aromatic and medicinal plants against growth of phytopathogenic bacteria. Agron. Res. 4, 437-440.

Vidhyasekaran, P. (2002). Bacterial Disease Resistance in Plants: Molecular Biology and Biotechnological Applications. Binghamton, NY: The Haworth Press.

Viljoen, A. M., Petkar, S., Vuuren, S. F., Figueiredo, A. C., Pedro, L. G., and Barroso, J. G. (2006). The chemo-geographical variation in essential oil composition and the antimicrobial properties of "Wild Mint" - Mentha longifolia subsp. polyadena (Lamiaceae) in Southern Africa. J. Essent. Oil Res. 18, 60-65.

Vishvakarma, P., Pandey, A. K., Mishra, P., Singh, P., and Tripathi, N. N. (2015). Enhancement of Shelf Life of Agaricus bisporus Lang from dry bubble disease (Verticillium fungicola var. fungicola) by fumigant application of Lippia alba rich essential oil. Int. J. Med. Mushrooms 17, 87-92. doi: 10.1615/ IntJMedMushrooms.v17.i1.90

Wagan, T. A., Hu, D., and He, Y. (2016). Repellency of three plant essential oils against red flour beetle Tribolium castaneum (Herbst, 1797) (Coleoptera: Tenebrionidae). Turk. J. Entomol. 40, 347-354. doi: 10.16970/ted.67713

Xu, J., Zhou, F., Ji, B. P., Pei, R. S., and Xu, N. (2008). The antibacterial mechanism of carvacrol and thymol against Escherichia coli. Lett. Appl. Microbiol. 47, 174-179. doi: 10.1111/j.1472-765X.2008.02407.x
Yadegarinia, D., Gachkar, L., Rezaei, M. B., Taghizadeh, M., Astaneh, S. A., and Rasooli, I. (2006). Biochemical activities of Iranian Mentha piperita L. and Myrtus communis L. essential oils. Phytochemistry 67, 1249-1255.

Zenali, H., Arzani, A., Razmjoo, K., and Rezaee, M. B. (2005). Evaluation of oil compositions of Iranian mints (Mentha ssp.). J. Essent. Oil Res. 17, 156-159. doi: 10.1080/10412905.2005.9698863

Zhang, W. J., Yang, K., You, C. X., Wang, C. F., Geng, Z. F., Su, Y., et al. (2015). Contact toxicity and repellency of the essential oil from Mentha haplocalyx Briq. against Lasioderma serricorne. Chem. Biodivers. 12, 832-839. doi: 10.1002/cbdv. 201400245

Conflict of Interest Statement: The authors declare that the research was conducted in the absence of any commercial or financial relationships that could be construed as a potential conflict of interest.

Copyright (C) 2018 Singh and Pandey. This is an open-access article distributed under the terms of the Creative Commons Attribution License (CC BY). The use, distribution or reproduction in other forums is permitted, provided the original author(s) and the copyright owner(s) are credited and that the original publication in this journal is cited, in accordance with accepted academic practice. No use, distribution or reproduction is permitted which does not comply with these terms. 